2006-1765: SEISMIC DESIGN EDUCATION IN SCHOOLS OF ARCHITECTURE

Christine Theodoropoulos, University of Oregon 


\title{
Seismic Design Education in Schools of Architecture
}

\begin{abstract}
Currently, no comprehensive or coordinated information exists on seismic design education for architects and architecture students in the United States. This subject deserves attention, particularly in view of recent trends toward the nationalization and globalization of architectural practice. Many architects, educated and based in areas of infrequent seismicity, find themselves more and more frequently required to design in regions of the U.S. or abroad where the seismic hazard is more serious. Unfortunately, this has not been adequately reflected in architectural education. Architects assume a pivotal role in seismic resistant design and are responsible for communicating seismic resistant strategies to building owners and community leaders. It is important that seismic design educators and practitioners understand how seismic design is currently taught in schools of architecture in order to identify new avenues for seismic design education and disseminate best teaching practices.
\end{abstract}

This paper reports on findings from: a survey of professors who teach structures in the U.S. schools accredited by the National Architectural Accrediting Board (NAAB); a review of school catalog materials; and an examination of school performance related to relevant student performance criteria used in the accreditation process. It includes a review of the seismic design content of architecture programs and the methods used to teach seismic design in an effort to chart how students learn seismic design concepts at various institutions. Findings include information about regional influences and the professional profile of instructors as well as faculty assessment of currently available teaching materials and identification of future teaching materials needs. Most significant is evidence suggesting that although most schools of architecture address the concepts central to seismic design across the curriculum in a variety of courses, there are barriers that may prevent students from learning how to incorporate seismic design lessons into the architectural design process.

\section{Background}

In the past two decades the National Science Foundation (NSF) and the Federal Emergency Management Agency (FEMA) have funded several projects directed to architectural education. Recently, the Earthquake Engineering Research Institute (EERI), with the support of FEMA, completed Designing for Earthquakes, a manual for practicing architects that was developed in response to the need for a text that consolidated information needed by architects preparing for practice in earthquake country. 
In 2000, the Building Science Safety Council (BSSC), with the support of FEMA, funded the development of a number of modules of a slide show directed to architects, predominantly related to the FEMA publications on the NEHRP Provisions for New Buildings and the publication on the Seismic Rehabilitation of Existing Buildings. These presentations have been given to a number of AIA continuing education classes but have had limited reach into the required curricula in schools of architecture.

In 1995, following the great Hanshin-Awaji Earthquake, NSF funded a team from the American Institute of Architects (AIA), in cooperation with the Japan Institute of Architects (JIA), to visit Kobe to focus on architecture and planning issues of reconstruction. Subsequently, in 1996 a joint AIA/JIA workshop was held in Washington, DC and a set of proceedings was published entitled "Architectural and Planning Lessons from the Great Hanshin-Awaji Earthquake.

Prior to this work a number of seminars for architects were developed and presented through support by FEMA to the AIA and the Association of Collegiate Schools of Architecture (ACSA) through the AIA/ACSA Council on Research. Later, derived from these seminars, a self-study course was developed that includes a short textbook and a videotape: this course was aimed at the AIA Continuing Education program. However, the work was not followed up, the course is no longer available, and the AIA/ACSA Council on Research was disbanded and reconstituted into the Institute for Architectural Research (IAR), which ceased to be active in 2003. Unfortunately in the process, past initiatives related to seismic design education for architects have been disregarded and resources are becoming out-of-date and out-of-print.

In addition to the seminars, two institutes on seismic design education involved architectural faculty members teaching general building design. This activity culminated in a charrette--a three-day, hands-on design course-- held in Los Angeles in 1997. In this course, faculty/student teams from a number of Los Angeles architectural schools participated in a Rapid Visual Screening exercise in Pasadena, California, designed information kiosks for use at FEMA disaster sites, and finally, constructed full size prototypes of the kiosks using wood frame construction and requiring some seismic calculations and construction detailing. In 1998 the AIA/ACSA team organized a national student design competition for the design of seismically resistant housing on a site in Hollywood, California.

These projects gave researchers some experience in the possibilities and constraints involved in teaching seismic design, both to students and practitioners. In addition researchers gained understanding of the state of seismic design education at architectural schools that enabled them to develop a list of faculty members involved in teaching, using a variety of approaches. This experience provided a valuable foundation upon which to develop a more systematic and extensive survey of seismic design education. 


\section{Project Approach}

Information about the seismic design education of architects in the United States was gathered using the following methods:

- A review of recent studies of building technology education in U.S. schools of architecture.

- Analysis of data provided by the National Architectural Accrediting Board (NAAB).

- A survey of faculty members most familiar with the seismic design curriculum at schools of architecture accredited by NAAB.

- An examination of architecture school catalogs and course information available on the internet. (This method was used to assist the survey process and augment information gathered in the survey.)

- Bibliographic research and a review of data collected in prior studies of building technology education in U.S. schools of architecture.

Based on this information the project team developed recommendations for approaches to improving seismic design education in schools of architecture.

\section{NAAB Accredited Programs in Earthquake Country}

The NAAB accredits professional programs offering the Bachelor of Architecture (B.Arch.), Master of Architecture (M.Arch.) and Doctor of Architecture (D.Arch.) degrees. Most state architectural licensure boards identify completion of an accredited degree as the minimum educational requirement to qualify for architectural licensure. There are currently 114 accredited architecture programs in the United States. The distribution of schools and programs in relation to the United States Geological Survey (USGS) ranking of states according to earthquake activity is shown in the table below. 


\begin{tabular}{|c|c|c|c|c|c|}
\hline $\begin{array}{l}\text { USGS GROUPING OF } \\
\text { STATES BY EARTHQUAKE } \\
\text { ACTIVITY }\end{array}$ & SCHOOLS & $\begin{array}{l}\text { APPROXIMATE } \\
\text { NO. OF } \\
\text { STUDENTS } \\
\text { ENROLLED }\end{array}$ & B.ARCH & M.ARCH & D.ARCH \\
\hline $\begin{array}{l}\text { Top ten: Alaska, } \\
\text { California, Hawaii, } \\
\text { Nevada, Washington, } \\
\text { Idaho, Wyoming, } \\
\text { Montana, Utah, Oregon }\end{array}$ & 17 & 4,500 & 9 & 12 & 1 \\
\hline $\begin{array}{l}\text { Second Ten: New } \\
\text { Mexico, Arkansas, } \\
\text { Arizona, Colorado, } \\
\text { Tennessee, Missouri, } \\
\text { Texas, Illinois, } \\
\text { Oklahoma, Maine }\end{array}$ & 21 & 4,200 & 10 & 18 & 0 \\
\hline $\begin{array}{l}\text { At least one Magnitude } \\
3.5 \text { and greater earthquake } \\
\text { in } 30 \text { years: New York, } \\
\text { Alabama, Kentucky, } \\
\text { South Carolina, South } \\
\text { Dakota, Virginia, } \\
\text { Nebraska, Ohio, Georgia, } \\
\text { Indiana, New Hampshire, } \\
\text { Pennsylvania, Kansas, } \\
\text { North Carolina, } \\
\text { Massachusetts, Michigan, } \\
\text { Minnesota, Mississippi, } \\
\text { New Jersey, Louisiana, } \\
\text { Rhode Island, West } \\
\text { Virginia }\end{array}$ & 59 & 14,100 & 39 & 40 & 0 \\
\hline $\begin{array}{l}0 \text { Magnitude } 3.5 \text { and } \\
\text { greater earthquake in } 30 \\
\text { years: Connecticut, } \\
\text { Delaware, Florida, Iowa, } \\
\text { Maryland, North Dakota, } \\
\text { Vermont, Wisconsin } \\
\text { (Washington D. C. and } \\
\text { Puerto Rico included) }\end{array}$ & 17 & 2,600 & 7 & 11 & 0 \\
\hline
\end{tabular}

Only 4,500 or $18 \%$ of architecture students enrolled in accredited degree programs in the United States are studying at schools located within the top ten most seismically active states where public awareness of seismic design is highest and the local community of practicing architects is more experienced with seismic design. 
Many schools of architecture in the United States offer bachelor's degrees and master's degrees of architecture that are not accredited. Students who wish to pursue professional licensure often combine these non-accredited degrees with accredited ones. Four typical paths students may take to obtain an accredited professional education are:

\begin{tabular}{|c|l|l|}
\hline 1 & Bachelor of Architecture (accredited) & \\
\hline 2 & & $\begin{array}{l}\text { Master or Doctorate of } \\
\text { Architecture (accredited) }\end{array}$ \\
\hline 3 & $\begin{array}{l}\text { Bachelor of Art or Science in Architecture or } \\
\text { Design (not accredited)** }\end{array}$ & $\begin{array}{l}\text { Master or Doctorate of } \\
\text { Architecture (accredited) }\end{array}$ \\
\hline 4 & Undergraduate Degree in another field & $\begin{array}{l}\text { Master or Doctorate of } \\
\text { Architecture (accredited) }\end{array}$ \\
\hline
\end{tabular}

*In recent years several Bachelor of Architecture programs have been converted to Master of Architecture programs that provide students with a continuous path toward the master's degree.

**Coursework completed in these non-accredited architecture programs may be used to meet some of the NAAB student performance criteria, hence a portion of a student's professional education can be completed in a non-accredited program. In most cases schools offering unaccredited undergraduate programs also offer an accredited graduate program that builds on the undergraduate curriculum.

The NAAB accreditation process evaluates all accredited programs, regardless of degree type, according to the same student performance criteria.

\section{NAAB Student Performance Criteria Related to Seismic Design}

The 1998 criteria (revised in 2002) for student performance identified 37 subject areas that must be included in accredited programs. A new version of this document with 34 criteria was adopted in 2004. Although student performance criteria that specifically address structural systems are most likely to address earthquake resistant design directly, other subject areas address issues relevant to the practice of seismic design. The Criteria, with changes adopted from the 2004 document, include:

- Structural Systems: Understanding of the principles of structural behavior in withstanding gravity and lateral forces, and the evolution, range, and appropriate applications of contemporary structural systems

- Building Systems Integration: Ability to assess, select, and conceptually integrate structural systems, building envelope systems, environmental 
systems, life-safety systems, and building service systems into building design

- Comprehensive Design: Ability to produce a comprehensive architectural project based on a building program and site that includes development of programmed spaces demonstrating an understanding of structural and environmental systems, life safety provisions, wall sections, and building assemblies, and the principles of sustainability.

- Site Conditions: Ability to respond to natural and built site characteristics in the development of a program and design of a project.

- Building Code Compliance: Understanding of the codes, regulations and standards applicable to a given site and building design, including occupancy classifications, allowable building heights and areas, allowable construction types, separation requirements, occupancy requirements, means of egress, fire protection, and structure. (This criterion was eliminated by NAAB in 2004)

- Legal Responsibilities: Understanding of the architect's responsibility as determined by registration law, building codes and regulations, professional service contracts, zoning and subdivision ordinances, environmental regulation, historic preservation laws and accessibility laws.

There is also a student performance criterion called "Life Safety." However NAAB evaluation of this criterion focuses primarily on design for egress. None of the 34 criteria for student performance include a specific mention of seismic design or design in response to natural hazards. The most closely related topic is the mention of lateral loads in the "Structural Systems" criterion.

\section{School Performance on Criteria Pertinent to Seismic Design Education}

As part of a self-study NAAB recorded the results of visiting team assessment of student performance criteria for the years 1999, 2000, 2002, and 2003. During these years 92 schools, $80 \%$ of the accredited schools in the U.S., were visited. The table below shows percent of schools that failed to meet student performance criteria related to seismic design.

\begin{tabular}{|l|r|}
\hline Structural Systems & $0 \%$ \\
\hline Building Systems Integration & $29.3 \%$ \\
\hline Comprehensive Design & $33.7 \%$ \\
\hline Site Conditions & $4.3 \%$ \\
\hline Legal Responsibilities & $6.5 \%$ \\
\hline Building Code Compliance $* * *$ & $14.1 \%$ \\
\hline
\end{tabular}


*** This student performance criterion was eliminated in 2004. Architects are currently expected to gain knowledge of this subject area after graduation during their professional internship.

Although all schools reviewed during this period met the student performance criterion for structural systems, and most schools met the criteria for site conditions and legal responsibilities of architects, approximately one third did not meet the performance criteria associated with comprehensive design and nearly $30 \%$ did not meet the criteria associated with building systems integration. These results suggest that accredited architecture programs provide students with a basic understanding of subjects needed to understand seismic design concepts but may not consistently prepare students to integrate technical systems into the architectural design process effectively.

\section{Survey of Seismic Design Educators}

The research team designed the survey to gather information about the following aspects of seismic design education:

- curricular context within which seismic design subjects are taught

- degree to which various seismic design topics are addressed in the required curriculum

- presence of elective and extra-curricular opportunities for students and continuing education opportunities for design professionals

- instructional methods used to present seismic design topics

- instructors' views about the appropriateness of design-based learning methods for teaching seismic design topics

- instructors' educational backgrounds, appointment types and teaching experience

- publications and other materials used to teach seismic design

- instructors' views about adequacy of currently available teaching materials and resources needed for teaching seismic design

- relative difficulty of the seismic design curriculum and its effectiveness at preparing students for the seismic design portion of the Architectural Registration Examination (ARE)

\section{Survey Administration and Participants}

114 schools accredited by the National Architectural Accrediting Board were invited to participate in the survey by an email sent to school administrators and through an article published in Connector, a newsletter distributed to building 
technology educators in schools of architecture. Through this process the research team identified professors who oversee the structures curriculum at 82 schools and contacted these individuals by email, phone or letter.

54 professors familiar with the seismic design curriculum at 54 schools completed the survey; 50 by phone and 4 by email. Data from 11 additional schools was gathered from university catalogs and course descriptions available on the internet. Data gathered in this study represents $57 \%$ of NAAB accredited schools and the response rate for individuals contacted was $66 \%$.

\section{Survey Analysis}

Analysis of the survey data identified the following problems.

- Architecture students learn most about structural aspects of seismic design and least about the seismic design of non-structural systems and components or the seismic design considerations relevant to site and regional planning. Some of the most important aspects of seismic design for architects - areas for which architects have primary responsibility are not included in required curricula. In most schools, seismic design is taught solely within structures courses.

- Seismic design education focuses primarily on new buildings. Architecture students have relatively little exposure to concepts related to the evaluation of existing buildings, retrofit design or approaches to protecting historic structures.

- Although computer aided design methods are used extensively in schools of architecture, fewer than half of the faculty teaching seismic design ask students to use computer models of building performance in their study of structural concepts.

- The majority of faculty members teaching seismic design in schools of architecture are structural engineers. $70 \%$ of the instructors surveyed reported that their highest degree was in engineering. 30\% have degrees in architecture.

- Interdisciplinary seismic design learning experiences that combine architecture and engineering students are uncommon and faculty crossover tends to be one-way with engineers actively teaching engineering principles to architecture students but architects rarely teaching architectural principles to engineering students.

- The majority of respondents (67\%) agreed that building design projects were an appropriate vehicle for teaching seismic design, however many identified obstacles to teaching seismic design concepts in the design studio. These include the need for students to acquire more theoretical 
background prior to beginning design, lack of willingness of studio faculty to prioritize seismic design issues and inadequate time available to teach this subject. Faculty members who advocated for a design-based learning approach identified the studio as an effective format for learning how to place principles into practice. The centrality of the design studio and the priority students and faculty place on the studio component of their academic programs was also seen as a good way to promote interest in the subject.

- The majority of respondents (57\%) believe that materials currently available for teaching seismic design concepts to architecture students were inadequate. When asked about their preferences for new teaching materials the most common requests were: case study examples, design based exercises or handbooks containing rules of thumb for the design studio, graphic presentations of qualitative seismic design concepts and comprehensive chapters on seismic design in general structures textbooks developed for architecture students. Only a few faculty members indicated that their students were required to read material in textbooks on seismic design and many acknowledged that the limited time available to cover the subject made it unrealistic to expect students to engage in in-depth readings or extensive projects dedicated to seismic study.

- The extent and content of seismic design education in schools of architecture is greatly influenced by the seismicity of the region where schools are located. Most schools located in high-wind regions reported that their coursework emphasized wind-resistant design with significantly less time spent on seismic design. Respondents also observed that studio design projects are sited primarily within the region where the schools are located so that students in less seismically active areas are unlikely to develop a design for an earthquake prone site. Several respondents in areas of low seismicity reported that their school's curriculum did not address seismic design specifically although general concepts related to lateral load resistance of structural systems were covered.

- The educational background and professional experience of the instructor can have a significant impact on the content of the seismic design curriculum. Faculty members with particular knowledge in seismic design tended to spend more time teaching seismic design content.

- The seismic design component of the structures curriculum is less challenging for students than the general structures curriculum but may be sufficient to prepare students for the architects' registration examination. Many instructors reported that they presented the seismic design portion of the structures curriculum qualitatively rather than quantitatively and that seismic study was perceived by students as being less difficult than other areas of their structures curriculum. Very few instructors reported using 
quantitative analysis, fieldwork and the construction of digital or physical models--teaching methods that require more hours of student engagement. However, the majority of respondents $(66 \%)$ predicted that students who completed their schools' structures curriculum were likely to be able to pass the lateral loads portion of the ARE without additional preparation because of the qualitative and conceptual emphasis of the exam content.

\section{Prior Studies of Building Technology Education in Schools of Architecture} In 2005, David J. Thaddeus at the University of North Carolina conducted a survey on technology education for the ACSA. The project was sponsored by the American Institute of Steel Construction (AISC) for the purpose of gathering information about structural steel education in schools of architecture. The survey also included other questions of interest to the ACSA. 92 faculty members teaching building technology subjects in accredited architecture programs in the US and Canada responded to questions about architectural education concerning school profiles; faculty qualifications and teaching assignments, curricular content and teaching materials. Only $8 \%$ of respondents said the subject of seismic structures was covered explicitly in the required curriculum. $6 \%$ responded that seismic design was addressed in advanced elective courses. A question concerning the need for teaching materials showed faculty requests for case studies $(12 \%)$, design rules of thumb $(11 \%)$ and visualizations of structural behavior (11\%).

In 1994, Daniel L. Faoro at the University of North Dakota surveyed faculty members teaching structures in schools of architecture. Surveys were sent to 117 schools and 58 responses were received. Over $60 \%$ of the respondents had graduate degrees in engineering, approximately one quarter of them had professional degrees in architecture. $10 \%$ of respondents reported that seismic design was their primary research area. Many different structures textbooks were in use; no book on seismic design was mentioned as a required or recommended text for structures courses. $28 \%$ reported having elective seminars on specialized structures topics; but only one school reported offering a seminar on seismic design. $11 \%$ reported that the studio curriculum at their schools included special topics studios in structures. When asked to rank the emphasis placed in the structures curriculum of various topical areas, most respondents ranked quantitative analysis and qualitative understanding of structural behavior above design applications. The lowest ranked subject areas were history of structural development and use of computer simulations. $74 \%$ of respondents agreed that closer integration of technical courses and studio instruction is needed.

\section{Conclusions and Recommendations}

All of the sources consulted in this study: the NAAB, the surveys of seismic design educators and prior surveys on building technology education confirm that architectural educators and professional evaluators of architecture programs believe that architecture schools can do a better job at teaching students how to integrate technical aspects of building design into the architectural design process. 
The failure to integrate seismic study into the design curriculum in schools of architecture appears to be due to the compartmentalization of seismic design education into a relatively small portion of structures coursework usually taught by individuals who are not qualified to teach architectural design studio. Many instructors responsible for the seismic design portion of their school's curriculum expressed frustration at the lack of time available to teach the subject and the lack of follow through in design studios which are the focus of students' design experience and occupy the center of schools' curricula. Architecture students who do study seismic design tend to do so in the context of learning about structural systems - an aspect of design that is primarily the responsibility of engineers and do not study aspects of seismic design, related to non-structural systems or site planning--areas that are primarily the responsibility of architects. Even though the professional practice of architecture increasingly crosses national and international borders, regionalism prevails at schools of architecture, particularly in the design studio component of student experience. Most students do not have the opportunity to undertake a design project that address natural hazards that are not prevalent in their region.

The need for curricular development in the area of seismic design is clear, however structural changes to curricula in schools of architecture can be difficult to implement. It is unlikely that schools will have the financial or time resources available to add or expand courses or hire specialized faculty members to teach seismic design. Given these constraints, future seismic design initiatives in architectural education should emphasize faculty development programs that engage instructors who teach design studio, professional practice and other coursework in subject areas other than structures. The primary audience for past initiatives in seismic design education aimed at architecture faculty has been structures instructors. This is partly due to self-selection-structures instructors are interested in the subject and volunteer to participate; and partly due to choices made by school administrators who tend to forward calls for seismic design opportunities to structures faculty. Although there has been some involvement of design studio instructors from California schools, past initiatives in seismic design education have not reached faculty responsible for teaching architectural design studio.

For faculty development programs to be successful they must be relevant to the teaching and research interests of the faculty and provide incentives for faculty participation. Addressing seismic design in a way that connects to subject areas across the curriculum where faculty members have teaching responsibility can increase relevance. Incentives can include stipends to assist in covering the cost of participation, but longer-term results may be achieved if professional development programs assist junior faculty in attaining promotion and tenure through competitive grant awards, peer reviewed publication, national recognition of teaching achievement and opportunities to contribute to research projects. 
There is a pressing need for new and revised teaching materials that support the integration of seismic design into the broader contexts of architectural design. The available literature on seismic design is inadequate because it does not provide architecture students with information that is at an appropriately rigorous level in a visual format. Seismic design information in standard textbooks that are required for building technology courses lacks rigor. Architecture students respond best to information presented graphically because graphic inquiry is central to the architectural design process. Case studies were among the most frequently requested materials. Some respondents recommended that emphasis be placed on case studies that are recognized for overall architectural excellence. The examination of case studies and learning from precedents is a standard practice across the curriculum in architectural education. Teaching materials projects that address the insertion of seismic design information into case studies that are already used in other subject areas may be an effective strategy to raise student and faculty awareness of seismic design and provide convincing illustrations of the integration of seismic design into the broader context of architectural design.

Demonstration projects that build upon existing frameworks in architectural education can be used to promote broader understandings of the architect's role in seismic design. Data from this study confirms that every school of architecture is unique. Missions of the schools and the stakeholders schools serve shape diverse approaches to architectural education. Although all accredited schools must meet the student performance criteria established by the NAAB, coursework in schools of architecture is not standardized. Faculty members develop courses in response to the school's context and instruction is tailored to the specific needs and interests of the students and faculty members at a particular school. A review of course syllabi collected as part of the faculty survey suggest that there are few, if any, examples of best practices in seismic design education that are readily transferable to a majority of architecture programs. Most depend on the ability of uniquely qualified faculty or access to regional professional resources in areas of high seismicity. The development of demonstration projects that are carefully designed for transferability could help schools address seismic design efficiently and effectively. These projects could examine ways to access expertise from outside of an architecture department and test ways to equip faculty members who are generalists rather than specialists. Motivation of student interest in seismic design is a key factor in advancing learning outcomes. Projects that demonstrate ways to engage students studying in regions of lower levels of seismicity in designing for earthquake country would be particularly valuable.

Earthquake community partnerships with national organizations that support excellence in architectural education could promote seismic design education. The two national organizations with the most direct links to the greatest number of architecture faculty members are the ACSA and the AIA. Both organizations undertake initiatives related to architectural education through committee work conducted by members and through research and service projects related to 
architectural education. Partnerships between architecture faculty and student organizations with organizations that support academic and professional interests has been very effective within the green design community and there are many lessons to be learned from examining the shift that has taken place in the area of sustainable design from an activity driven by specialists to one driven by generalists. Vehicles to consider are: the committees of the AIA, especially the AIA's Knowledge Communities with interests in building performance and in education; programs administered by the ACSA, particularly the association's student competition and curriculum development projects; and the national and regional meetings of the ACSA, the AIA and the American Institute of Architecture Students (AIAS).

Finally, it is clear from an analysis of the NAAB student performance criteria that schools of architecture and accreditation review teams do not receive a specific directive to address seismic design or disaster resistant design in the curricula of architecture schools. The development of a white paper containing proposals for revisions to the NAAB student performance criteria would be an effective strategy for moving disaster resistant design onto the agenda of a national dialog that involves the ACSA, the AIA, the AIAS and the National Council of Architectural Registration Boards (NCARB), the five collaterals that comprise NAAB.

\section{Bibliography}

1. American Institute of Architects.1996. Architectural and Planning Lessons from the Great Hanshin-Awaji Earthquake, 1995, American Institute of Architects, Washington, DC.

2. American Institute of Architects/Association of Collegiate Schools of Architecture.1994. Buildings at Risk, American Institute of Architects, Washington, DC.

3. Building Seismic Safety Council. 2000. Presentations for the Architectural Community,

4. Building Seismic Safety Council, Washington, DC.

5. Faoro, Daniel, L.1994 Structures Curriculum Survey, a report of the Department of Architecture, North Dakota State University, Fargo, North Dakota.

6. The Earthquake Engineering Research Institute (EERI). 2006. Designing for Earthquakes: a Manual for Practicing Architects, The Federal Emergency Management Agency, Washington, DC.

7. The National Architectural Accrediting Board. 2005. NAAB Conditions for Accreditation for Professional Degree Programs in Architecture, 2004 edition, The National Architectural Accrediting Board, Washington, DC.

8. The National Architectural Accrediting Board. 2003. NAAB Conditions for Accreditation for Professional Degree Programs in Architecture, 2002 edition, The National Architectural Accrediting Board, Washington, DC.

9. The National Architectural Accrediting Board. 1999. NAAB Conditions for Accreditation for Professional Degree Programs in Architecture, 1998 edition, The National Architectural Accrediting Board, Washington, DC.

10. The National Architectural Accrediting Board. 2005. NAAB Statistics Report 2004, The National Architectural Accrediting Board, Washington, DC. 
11. The National Architectural Accrediting Board. 2005. Unpublished student performance criteria data from 1999, 2000, 2002, 2003. The National Architectural Accrediting Board, Washington, DC.

12. Thaddeus, David J. 2005. Technology Education in Colleges of Architecture in North America, American Institute of Steel Construction Project Report, AISC, Chicago, Illinois.

13. United States Geological Survey Ranking of states by earthquake activity at:

14. http://neic.usgs.gov/neis/states/top_states.html 